\title{
Genetic Diversity Studies in Kodo Millet (Paspalum scrobiculatum L.) Germplasm Accessions Based on Biometrical and Nutritional Quality Traits
}

\author{
V. Nirubana ${ }^{1 *}$, K. Ganesamurthy ${ }^{1}$, R. Ravikesavan ${ }^{2}$ and T. Chitdeshwari ${ }^{3}$ \\ ${ }^{1}$ Centre for Plant Breeding and Genetics, ${ }^{2}$ Department of Millets, Centre for Plant Breeding and \\ Genetics, ${ }^{3}$ Department of Soil Science and Agricultural Chemistry, Tamil Nadu Agricultural \\ University, Coimbatore - 641 003, Tamil Nadu, India \\ *Corresponding author
}

\section{A B S T R A C T}

\begin{tabular}{|l|}
\hline Key w or d s \\
Paspalum \\
scrobiculatum $\mathrm{L} .$, \\
Genetic divergence, \\
$\mathrm{D}^{2}$ analysis. \\
\hline Article Info \\
\hline $\begin{array}{l}\text { Accepted: } \\
\text { 07 September } 2017 \\
\text { Available Online: } \\
\text { 10 October } 2017\end{array}$ \\
\hline
\end{tabular}

In the present study, an attempt was made to assess the genetic divergence among the 103 kodo millet germplasm accessions using Mahalanobis $\mathrm{D}^{2}$ statistic collected from Millet Breeding Station, Coimbatore. The observations were recorded on yield components and nutritional quality traits. The 103 germplasm lines were grouped into 11 different clusters based on $\mathrm{D}^{2}$ analysis. Cluster I had a maximum of 63 genotypes, followed by clusters II and III with 14 each, cluster X with four genotypes and cluster VIII with two genotypes. Remaining clusters IV, V, VI, VII, IX and XI were mono-genotypic indicating wide divergence from other clusters. The highest intra cluster distance was observed in cluster $\mathrm{X}$ indicating differences in genotypes within cluster. The highest inter-cluster distance was observed between clusters III and X followed by clusters IV and VII suggesting the use of genotypes from these clusters to serve as potential parents for hybridization. The characters days to 50 per cent flowering contributed maximum towards divergence followed by Fe content, $\mathrm{Zn}$ content and grain yield per plant.

\section{Introduction}

Kodo millet is a tropical small millet crop, which is indigenous to India (de Wet et al., 1983) and grown for its grain and fodder. It is widely distributed in damp habitats across the tropics and subtropics of the world. In India, kodo millet occupies an area of 152.5 thousand hectares with the production and productivity of 41.2 thousand tones and 312 $\mathrm{kg} / \mathrm{ha}$, respectively (Padulosi et al., 2009) and 3570 hectares of area and 6187 tonnes of production in Tamil Nadu (Season and Crop Report 2013-14). Among the small millets, productivity per unit area is highest in kodo millet (Ahamed and Yadava, 1996). It matures in three to four months with yields varying from 250 to $1000 \mathrm{~kg} / \mathrm{ha}$ (Hulse et al., 1980 ) and a potential yield of $2000 \mathrm{~kg} / \mathrm{ha}$ (Harinarayana, 1989). The seeds have an excellent storage life and can be stored for several years (Hegde and Gowda, 1989). The quest for increasing yield is though, a primary concern for an increasing world population which has achieved self-sufficiency in food production quantitatively, but not in quality. Hence, priority of breeders may be to breed for quality with higher amount of micronutrients especially iron $(\mathrm{Fe})$ and zinc (Zn) which is most frequent deficient minerals in cereal based human diets and globally estimated that five million people are 
deficient in both the elements. Health consciousness among the consumers in recent years has shifted interest to traditional millet crops like kodo millet. The Kodo millet contains 9.8g Protein, 3.6g Fat, 3.3g Ash, $5.2 \mathrm{~g}$ Crude fibre, $66.6 \mathrm{~g}$ Carbohydrate, $353 \mathrm{k}$ cal energy, $35 \mathrm{mg}$ Calcium, $1.7 \mathrm{mg}$ Iron, 0.15 $\mathrm{mg}$ Thiamin, $0.09 \mathrm{mg}$ Riboflavin and $2.0 \mathrm{mg}$ Niacin (Hulse et al., 1980).

Being drought tolerant, the nutritional value of the protein has been found to be slightly better than that of foxtail millet but comparable to that of other small millets and has high levels of micronutrients, dietary fiber content and low glycemic index (GI) with potential health prospective (Chandel et al., 2014; Dwivedi et al., 2012; Saleh et al., 2013), anti-oxidants (Chandrasekara and Shahidi 2010) and anti-diabetes principles (Hegde et al., 2005). Till recently, only few genetic studies have been carried out for micronutrients especially for grain $\mathrm{Fe}$ and $\mathrm{Zn}$.

Thus, improvement in nutritive quality of grains along with the sustained yield may prove useful for alleviating malnutrition. Aforesaid facts suggest that, kodo millet has all the potential and the success of any plant breeding programme largely depends on the existence of diversity among the genotypes (Allard, 1960). The study was conducted to determine genetic diversity for yields and its components among genotypes is important for planning the future crossing programme using Mahalanobis $\mathrm{D}^{2}$ statistics and different clustering procedures, based on yield and its component characters and assessing the relative contribution of different components to total divergence (Rao, 1952).

\section{Materials and Methods}

The experimental materials consisted of 103 kodo millet genotypes and were grown in a randomized block design with three replications at the Millet Breeding Station, Tamil Nadu Agricultural University (TNAU), Coimbatore during kharif 2015- 2016. Standard agronomic practices and plant protection measures were taken as per schedule. Observations regarding 13 morphological traits viz., days to first flowering, days to 50 per cent flowering, plant height, number of basal tillers, number of productive tillers, flag leaf length, flag leaf width, peduncle length, inflorescence length, length of longest raceme, thumb length, thousand grain weight and grain yield per plant were recorded in three randomly selected plants in each replication and for nutritional quality traits ( $\mathrm{Zn}$ and Fe content), the whole grain samples were finely ground and the samples were then oven dried at $60^{\circ} \mathrm{C}$ for 48 hours before analysis. $\mathrm{Fe}$ and $\mathrm{Zn}$ content was determined by diacid mixture (sulphuric acid: perchloric acid) method (Piper, 1966) and measured by using Atomic Absorption Spectrophotometer (AAS). Iron and zinc content estimated at Department of Soil Science and Agricultural Chemistry, TNAU. The genetic diversity between the genotypes was worked out using Mahalanobis $\mathrm{D}^{2}$ (1936) statistics and grouping of genotypes into clusters was done using Tocher's method (Rao, 1952).

\section{Results and Discussion}

Analysis of variance showed significant differences among the genotypes for all the characters studied. Based on $\mathrm{D}^{2}$ value, 103 genotypes were grouped into 11 clusters (Table 1) (Fig. 1). The distribution pattern of the genotypes into clusters indicated that cluster I was the largest, containing 63 genotypes followed by cluster II and III with 14 genotypes, cluster $\mathrm{X}$ with four genotypes and cluster VIII with two genotypes. Six clusters IV, V, VI, VII, IX and XI were solitary containing one genotype each. Solitary clusters revealed the presence of 
wide genetic divergence for various characters among these genotypes.

Padmaja (1998) in little millet and Ulaganathan and Nirmalakumari (2015) in finger millet also observed solitary clusters in their study. The presence of solitary clusters indicated extreme phenotypic performance in positive or negative directions for one or the other characters.

The intra and inter-cluster distance analysis indicated that the maximum intra-cluster distance was observed for cluster X (17.08) followed by cluster III (13.61), cluster II (12.15), cluster I (11.69) and cluster VIII (7.85) (Table 2). This suggested that the genotypes in cluster $\mathrm{X}$ were relatively more diverse among themselves. Similar findings were reported by Shinde et al., (2013) in finger millet. Genotypes falling between cluster III and $\mathrm{X}$ exhibited maximum intercluster distances (33.02), showing high degree of genetic diversity indicating that genetic makeup of genotypes falling in this cluster may be entirely different from one another and thus may be utilized for future breeding programme for getting high yielding genotypes. These results of genetic diversity study were in agreement with the finding of Wolie et al., (2013) and Dinesh et al., (2010) in finger millet. Therefore the genotypes of most diverse cluster may be used as parents in hybridization programmes to develop high yielding varieties.

Fig.1 Dendrogram based on $\mathrm{D}^{2}$ values for fifteen characters in kodo millet

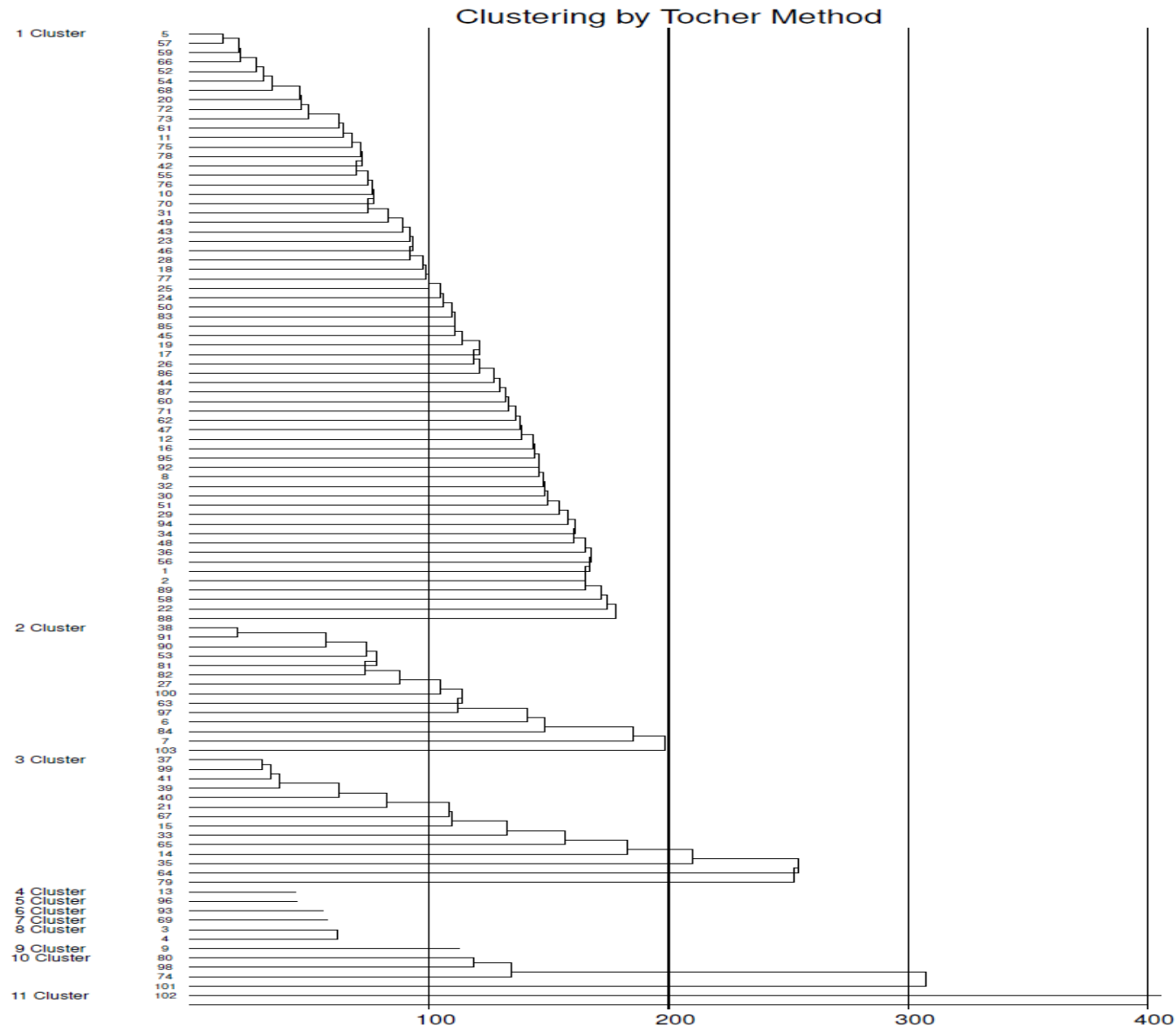


Table.1 Distribution of 103 genotypes into 11 clusters based on fifteen characters

\begin{tabular}{|c|c|c|}
\hline Clusters & $\begin{array}{l}\text { Number of } \\
\text { genotypes }\end{array}$ & Accession number \\
\hline I & 63 & 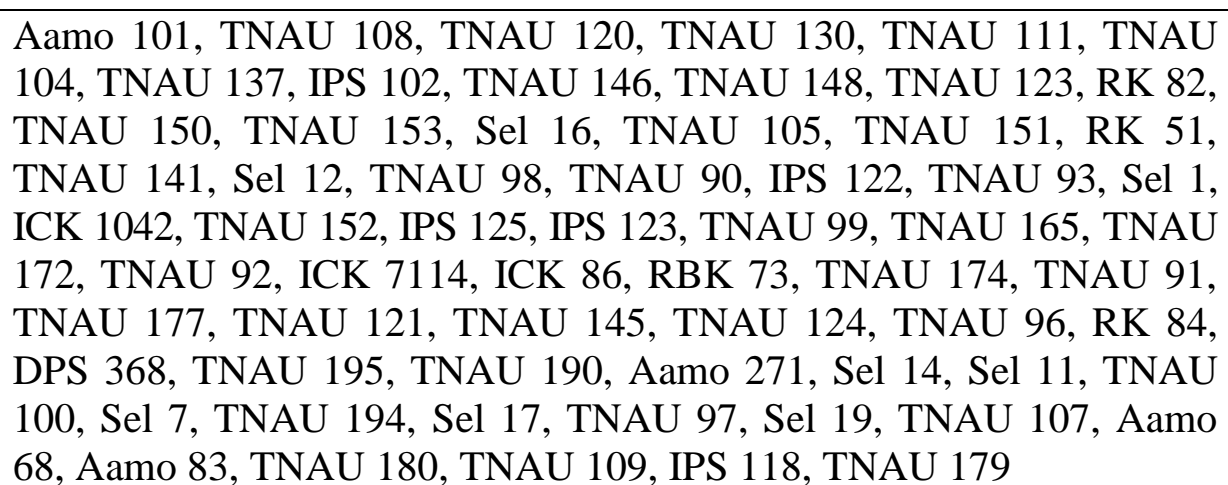 \\
\hline II & 14 & $\begin{array}{l}\text { Sel } 21 \text {, TNAU } 188 \text {, TNAU 187, TNAU } 102 \text {, TNAU } 162 \text {, TNAU } 164 \text {, } \\
\text { RBK } 155 \text {, Sel 16, TNAU 127, TNAU 201, Aamo 126, TNAU 17, } \\
\text { Aamo } 258 \text {, TNAU } 86\end{array}$ \\
\hline III & 14 & $\begin{array}{l}\text { Sel } 20 \text {, GPUK } 3 \text {, TNAU } 85 \text {, TNAU } 82 \text {, TNAU } 84 \text {, IPS } 113 \text {, TNAU } \\
\text { 133, DPS } 95 \text {, Sel } 15 \text {, TNAU 129, RK } 162 \text {, Sel } 18 \text {, TNAU } 128 \text {, TNAU } \\
154\end{array}$ \\
\hline IV & 1 & RK 111 \\
\hline $\mathrm{V}$ & 1 & TNAU 197 \\
\hline VI & 1 & TNAU 191 \\
\hline VII & 1 & TNAU 140 \\
\hline VIII & 2 & Aamo 89, Aamo 90 \\
\hline IX & 1 & RK 50 \\
\hline $\mathrm{X}$ & 4 & TNAU 155, TNAU 236, TNAU 149, CO 3 \\
\hline $\mathrm{XI}$ & 1 & APK 1 \\
\hline
\end{tabular}

Table.2 Intra (diagonal) and inter cluster average distances among eleven clusters for 15 characters in kodo millet

\begin{tabular}{|c|c|c|c|c|c|c|c|c|c|c|c|}
\hline Cluster & I & II & III & IV & V & VI & VII & VIII & IX & X & XI \\
\hline I & $\mathbf{1 1 . 6 9}$ & 16.11 & 15.35 & 14.56 & 14.49 & 15.39 & 13.75 & 15.65 & 23.06 & 25.80 & 29.35 \\
\hline II & & $\mathbf{1 2 . 1 5}$ & 22.90 & 16.71 & 17.47 & 16.88 & 19.73 & 15.88 & 16.53 & 19.31 & 25.80 \\
\hline III & & & $\mathbf{1 3 . 6 1}$ & 19.95 & 20.01 & 22.26 & 17.55 & 19.00 & 30.37 & 33.02 & 32.79 \\
\hline IV & & & & $\mathbf{0 . 0 0}$ & 8.45 & 11.20 & 12.48 & 22.53 & 17.64 & 21.16 & 27.50 \\
\hline V & & & & & $\mathbf{0 . 0 0}$ & 7.47 & 9.66 & 22.15 & 19.20 & 22.65 & 30.68 \\
\hline VI & & & & & & $\mathbf{0 . 0 0}$ & 11.72 & 21.75 & 18.90 & 20.52 & 32.59 \\
\hline VII & & & & & & & $\mathbf{0 . 0 0}$ & 22.66 & 23.18 & 26.62 & 31.72 \\
\hline VIII & & & & & & & & $\mathbf{7 . 8 5}$ & 26.59 & 27.50 & 29.26 \\
\hline IX & & & & & & & & & $\mathbf{0 . 0 0}$ & 14.40 & 26.59 \\
\hline X & & & & & & & & & & $\mathbf{1 7 . 0 8}$ & 29.15 \\
\hline XI & & & & & & & & & & & $\mathbf{0 . 0 0}$ \\
\hline
\end{tabular}

Tocher cut off value: 188 
Table.3 Cluster mean values for fifteen characters in kodo millet

\begin{tabular}{|c|c|c|c|c|c|c|c|c|c|c|c|c|c|c|c|}
\hline Cluster & DF & DFF & PH & NBT & PT & FLL & FLW & PL & IL & LLR & TL & TGW & $\mathbf{Z n}$ & $\mathbf{F e}$ & GY \\
\hline I & 57.23 & 60.24 & 58.20 & 16.65 & 6.16 & 13.74 & 0.68 & 5.34 & 12.45 & 6.06 & 5.67 & 3.59 & 3.76 & 15.55 & 15.14 \\
\hline II & 64.55 & 67.79 & 70.51 & 18.34 & 7.56 & 13.90 & 0.73 & 5.78 & 13.78 & 6.85 & 7.29 & 3.91 & 4.54 & 10.96 & 18.28 \\
\hline III & 52.02 & 54.83 & 44.03 & 18.26 & 6.08 & 12.23 & 0.68 & 4.63 & 11.55 & 5.56 & 4.91 & 3.57 & 1.95 & 15.74 & 11.88 \\
\hline IV & 61.67 & 65.33 & 71.09 & 18.89 & 5.40 & 16.36 & 0.76 & 6.93 & 12.59 & 5.94 & 5.71 & 3.67 & 0.20 & 20.48 & 18.64 \\
\hline $\mathbf{V}$ & 61.00 & 64.00 & 68.33 & 22.22 & 8.19 & 14.74 & 0.66 & 5.41 & 11.79 & 6.50 & 6.63 & 3.96 & 3.40 & 24.56 & 20.93 \\
\hline VI & 62.67 & 66.33 & 71.10 & 18.00 & 6.00 & 14.56 & 0.57 & 6.58 & 12.51 & 5.76 & 6.50 & 3.46 & 5.66 & 24.27 & 14.33 \\
\hline VII & 58.33 & 60.33 & 49.60 & 12.11 & 5.60 & 13.22 & 0.72 & 4.11 & 14.30 & 6.07 & 5.11 & 3.11 & 4.70 & 24.69 & 19.92 \\
\hline VIII & 58.33 & 61.67 & 54.63 & 22.89 & 8.82 & 15.18 & 0.69 & 5.86 & 11.97 & 4.71 & 5.30 & 4.01 & 6.50 & 6.93 & 10.43 \\
\hline IX & 70.67 & 75.33 & 79.90 & 14.67 & 9.00 & 11.69 & 0.71 & 6.94 & 19.26 & 8.32 & 11.62 & 4.73 & 1.21 & 15.56 & 22.89 \\
\hline $\mathbf{X}$ & 74.00 & 78.25 & 78.75 & 17.94 & 6.66 & 12.22 & 0.75 & 6.74 & 14.51 & 7.58 & 8.62 & 4.11 & 3.12 & 15.67 & 13.64 \\
\hline XI & 65.00 & 69.67 & 86.35 & 23.67 & 7.80 & 11.37 & 1.62 & 6.33 & 18.86 & 8.03 & 9.63 & 4.91 & 2.98 & 7.73 & 16.13 \\
\hline
\end{tabular}

Abbreviations used: DF- Days to first flowering (days); DFF- Days to 50 per cent flowering (days); PH- Plant height (cm); NBT-Number of basal tillers (count); PT- Number of productive tillers (count); FLL- Flag leaf length $(\mathrm{cm})$; FLW- Flag leaf width (cm); PL- Peduncle length (cm); IL- Inflorescence length (cm); LLR- Length of the longest raceme (cm); TL- Thumb length $(\mathrm{cm})$; TGW- Thousand grain weight $(\mathrm{g})$; Zn- Zinc content (mg/100g); Fe- Iron content (mg/100g); GY- Grain yield per plant (g). 
Table.4 Percentage contribution of fifteen characters to genetic divergence in 103 kodo millet genotypes

\begin{tabular}{|l|c|c|}
\hline \multicolumn{1}{|c|}{ Character } & Times Ranked 1st & Contribution \% \\
\hline Days to first flowering & 17 & 0.32 \\
\hline Days to 50\% flowering & 1815 & 34.55 \\
\hline Plant height $(\mathrm{cm})$ & 110 & 2.09 \\
\hline Number of basal tillers & 119 & 2.27 \\
\hline Number of productive tillers & 39 & 0.74 \\
\hline Flag leaf length $(\mathrm{cm})$ & 34 & 0.65 \\
\hline Flag leaf width $(\mathrm{cm})$ & 123 & 2.34 \\
\hline Peduncle length $(\mathrm{cm})$ & 3 & 0.06 \\
\hline Inflorescence length $(\mathrm{cm})$ & 44 & 0.84 \\
\hline Length of the longest raceme $(\mathrm{cm})$ & 9 & 0.17 \\
\hline Thumb length $(\mathrm{cm})$ & 3 & 0.06 \\
\hline Thousand grain weight $(\mathrm{g})$ & 40 & 0.76 \\
\hline Zn content $(\mathrm{mg} / 100 \mathrm{~g})$ & 790 & 15.04 \\
\hline Fe content $(\mathrm{mg} / 100 \mathrm{~g})$ & 1694 & 32.25 \\
\hline Grain yield per plant $(\mathrm{g})$ & 413 & 7.86 \\
\hline
\end{tabular}

A perusal of results of cluster means (Table 3) revealed that cluster IX exhibited highest mean value for the characters number of productive tillers (9.00), peduncle length $(6.94 \mathrm{~cm})$, inflorescence length $(19.26 \mathrm{~cm})$, length of the longest raceme $(8.32 \mathrm{~cm})$, thumb length $(11.62 \mathrm{~cm})$ and grain yield per plant $(22.89 \mathrm{~g})$. Cluster XI had highest mean value for plant height $(86.35 \mathrm{~cm})$, number of basal tillers (23.67), flag leaf width $(1.62 \mathrm{~cm})$ and thousand grain weight (4.91 g). Cluster VIII had highest mean value for flag leaf length $(15.18 \mathrm{~cm})$ and $\mathrm{Zn}$ content $(6.50 \mathrm{mg} / 100 \mathrm{~g})$. Cluster VII had highest mean value for $\mathrm{Fe}$ content $(24.69 \mathrm{mg} / 100 \mathrm{~g})$. The lowest mean value for days to first flowering (52.02), days to 50 per cent flowering (54.83) was shown by the cluster III. All the minimum and maximum cluster mean values were distributed in relatively distant clusters. However the cluster IX recorded highest mean value for most of the characters. Thereby recombination breeding between genotypes of different clusters could be done to combine the desirable characters of different accessions.
The selection and choice of parents mainly depends upon contribution of characters towards divergence (Table 4). The maximum contribution in the manifestation of genetic divergence was exhibited by $\mathrm{Fe}$ content followed by $\mathrm{Zn}$ content, days to 50 per cent flowering, grain yield per plant, flag leaf width, number of basal tillers and plant height suggesting scope for improvement in these characters. In other words, selection for these characters may be rewarding. Similar results were repored for $\mathrm{Zn}$ content and grain yield per plant in barnyard millet by Plawani Panda (2015). Shinde et al., (2013) for Iron content in finger millet, Ulaganathan (2013) in finger millet for days to 50 per cent flowering, Sirisha (2008) in foxtail millet for number of tillers and Manimozhi Selvi (2014) for grain yield per plant in little millet. Contribution of the characters towards diversity indicated that flowering time, $\mathrm{Fe}$ and $\mathrm{Zn}$ content had more variability among the lines. Hence the nutritional quality and the duration of the kodo millet can be targeted utilizing the variability showed among the lines tested. 


\section{References}

Ahamed, M.S., and Yadava, H.S. 1996. Assessment of productivity and economics of small millets in Madhya Pradesh. Crop Res. 12(3): 12-15.

Allard, R. W., 1960. Principles of plant breeding. Wiley and Sons Inc., New York.

Chandel, G., R.K. Meena, M. Dubey and Kumar, M. 2014. Nutritional properties of minor millets: neglected cereals with potentials to combat malnutrition. Current Sci. 107(7): 1109-1111.

Chandrasekra, A., and Shahidi, F. 2010. Content of insoluble bound phenolics in millets and their contribution to antioxidant capacity. J. Agric. Food Chem. 58, 6706-6714.

de Wet, J.M.J., K.E. Prasada Rao and Brink, D.E. 1983. Systematics and domestication of Panicum sumatrense (Graminae). J. d'agriculture Tradit. Bot. appliqué. 30, 159-168.

Dinesh, K., T. Vikrant, B.B. Ramesh and Sukram, P. 2010. Genetic Diversity in Finger Millet (Eleusine coracana L.). Crop Improv. 37(1): 25-28.

Dwivedi, S.L., H.D. Upadhyaya, S. Senthilvel, C.T. Hash, K. Fukunaga and Diao, X. 2012. Millets: genetic and genomic resources. In: Janick, J. (Ed.), Plant Breeding Reviews, vol. 35, John Wiley \& Sons, USA, pp. 247-375.

Harinarayana, G., 1989. Breeding and varietal improvement of Small Millets in India. In. Small millets in global agriculture. Proc. First Int. Small millets workshop. Bangalore. (Eds.) Seetharama, A., Riley, K.W and Harinarayana, G. Oxford and IBH publishing Co. Pvt. Ltd. New Delhi. pp 59-70.

Hegde, B.R., and Gowda, B.K.L. 1989. Cropping systems and production technology for small millets in India. In: Small Millets in Global Agriculture (eds. Seetharam, A., Riley, K.W. and Harinarayana, G.) India: IDRC, Oxford $\&$ IBH Co.

Hegde, P.S., and Chandra, T.S. 2005. ESR spectroscopic study reveals higher free radical quenching potential in kodo millet (Paspalum scrobiculatum) compared to other millets. Food Chem. 92, 177-182.

Hulse, J.H., E.M Liang and Pearson, O.E. 1980. Sorghum and the Millets: their Composition and Nutritive Value. New York Academic Press. 1997.

Jayalakshmi, C., 2010. Genetic divergence studies in finger millet (Eleusine coracana (L.) Gaertn.). J. Res., ANGRAU. 36(4): 126.

Manimozhi Selvi, V., 2014. Characterization and evaluation of little millet (Panicum sumatrense Roth ex Roem. and Schultz) genotypes for nutritional traits. Ph.D. Thesis, Tamil Nadu Agric. Univ., Coimbatore, India.

Padmaja, 1998. Studies on variability, correlation, path analysis and $\mathrm{D}^{2}$ analysis for yield and yield attributes in little millet (Panicum sumatrense Roth.). M.Sc. Thesis, Tamil Nadu Agric. Univ., Coimbatore, India.

Padulosi, S., B. Mal, S. Bala Ravi, J. Gowda, K.T.K. Gowda, G. Shanthakumar, N. Yenagi and Dutta, M. 2009. Food security and climate change: role of plant genetic resources of minor millets. Indian J. Plant. Genet. Resour. 22, 1-16.

Piper, J., 1966. Diffusion of Hydrogen in Copper-Palladium Alloys. J. Appl. Phys. 37(2): 715-721.

Plawani Panda, 2015. Genetic diversity in barnyard millet (Echinochola frumentacea Roxb.) using morphological and molecular markers. M.Sc. Thesis, Tamil Nadu Agri. Univ., Coimbatore, India.

Rao, C. R., 1952. Advanced statistical methods in biometrical research. Edn. I. 
John Wiley \& Sons, New York. Pp. 390.

Saleh, A.S.M., Q. Zhang, J. Chen and Shen, Q. 2013. Millet grains: nutritional quality, processing, and potential health benefits. Compr. Rev. Food Sci. Food Saf. 12(3): 281-295.

Season and Crop Report. 2013-2014. Department of Economics and Statistics, Chennai. Pp. 53.

Shinde, S.R., S. V. Desai and Pawar, R.M. 2013. Genetic diversity pattern in finger millet [Eleusine coracana (L.) Gaertn]. Electron. J. Plant Breed. 4(3): 1242-1245.

Sirisha, A.B.M., 2008. Character association and genetic divergence in italian millet [Setaria italica (L.) Beauv]. M.Sc.Thesis, Acharya N.G. Ranga Agric. Univ., Hyderabad.

Ulaganathan, V., 2013. Evaluation and characterization of genetic resources and stability analysis of selected genotypes in finger millet (Eleusine coracana (L.) Gaertn.). Ph.D. Thesis, Tamil Nadu Agric. Univ., Coimbatore, India.

Ulaganathan, V., and Nirmalakumari, A. 2015. Finger millet germplasm characterization and evaluation using principal component analysis. SABRAO J. Breed. Genet, 47(2): 7988.

Wolie, A., K. Belete and Dessalegn, T. 2013. Heritability, variance components and genetic advance of some yield and yield related traits in Ethiopian collections of finger millet (Eleusine coracana (L.) Gaertn.) Genotypes. African J. Biotechnol. 12(36): 5529-5534.

\section{How to cite this article:}

Nirubana, V., K. Ganesamurthy, R. Ravikesavan and Chitdeshwari, T. 2017. Genetic Diversity Studies in Kodo Millet (Paspalum scrobiculatum L.) Germplasm Accessions Based on Biometrical and Nutritional Quality Traits. Int.J.Curr.Microbiol.App.Sci. 6(10): 832-839. doi: https://doi.org/10.20546/ijcmas.2017.610.099 